\title{
Daar is hulp vir depressie!
}

\begin{tabular}{|c|c|}
\hline $\begin{array}{l}\text { Book Title: } \\
\text { Depressie - sin } \\
\text { oorsake en gen }\end{array}$ & $\begin{array}{l}\text { nptome, } \\
\text { nesing }\end{array}$ \\
\hline Book Cover: & \\
\hline 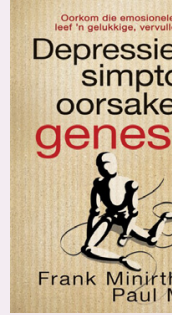 & $\begin{array}{l}\text { ing } \\
\text { ome, } \\
\text { ing en } \\
\text { ond low } \\
\text { Meier }\end{array}$ \\
\hline $\begin{array}{l}\text { Authors: } \\
\text { Frank Minirth } \\
\text { Paul Meier }\end{array}$ & \\
\hline $\begin{array}{l}\text { ISBN: } \\
978-1-4316-00\end{array}$ & $02-1$ \\
\hline $\begin{array}{l}\text { Publisher: } \\
\text { Vereeniging, Cl } \\
\text { Uitgewersmaa } \\
\text { R119.95* } \\
\text { *Book price at th }\end{array}$ & $\begin{array}{l}\text { hristelike } \\
\text { tskappy, 2013, } \\
\text { e time of review }\end{array}$ \\
\hline $\begin{array}{l}\text { Review Title: } \\
\text { Daar is hulp vir }\end{array}$ & depressie! \\
\hline $\begin{array}{l}\text { Reviewer: } \\
\text { Amanda L. du }\end{array}$ & Plessis ${ }^{1}$ \\
\hline $\begin{array}{l}\text { Affiliation: } \\
{ }^{1} \text { Department o } \\
\text { Theology, Nort } \\
\text { University, Pot } \\
\text { Campus, Potch } \\
\text { South Africa }\end{array}$ & $\begin{array}{l}\text { f Practical } \\
\text { h-West } \\
\text { chefstroom } \\
\text { efstroom, }\end{array}$ \\
\hline $\begin{array}{l}\text { Email: } \\
\text { amanda.duple }\end{array}$ & ssis@nwu.ac.za \\
\hline $\begin{array}{l}\text { Postal address } \\
\text { Department of } \\
\text { Theology, Nort } \\
\text { University, Inte } \\
\text { 147, Private Ba } \\
\text { Potchefstroom } \\
\text { South Africa }\end{array}$ & $\begin{array}{l}\text { Practical } \\
\text { h-West } \\
\text { g box } \\
25001 \\
2520\end{array}$ \\
\hline $\begin{array}{l}\text { How to cite th } \\
\text { Du Plessis, A.L. } \\
\text { is hulp vir depr } \\
\text { Skriflig } 48(1), A \\
2 \text { pages. http:/ } \\
\text { org/10.4102/ic }\end{array}$ & $\begin{array}{l}\text { is book review: } \\
\text {, 2014, 'Daar } \\
\text { essie!', In die } \\
\text { Art. \#1816, } \\
\text { /dx.doi. } \\
\text { ds.v48i1.1816 }\end{array}$ \\
\hline Read online: & $\begin{array}{l}\text { Scan this QR } \\
\text { code with your } \\
\text { smart phone or } \\
\text { mobile device } \\
\text { to read online. }\end{array}$ \\
\hline
\end{tabular}

Hierdie boek uit die pen van Frank Minirth en Paul Meier, is 'n vertaling van die oorspronklike werk, Happiness is a choice, wat in 1978 uitgegee en in 1994 hersien is. Dit is 'n boek waarsonder geen predikant, pastorale berader, maatskaplike werker of sielkundige behoort te wees nie!

Die outeurs is albei psigiaters en stigterslede van die bekende Minirth en Meier-klinieke in Amerika en Kanada. In hierdie klinieke word mense op 'n multidissiplinêre wyse tot heelwording en genesing begelei. Verskeie publikasies het al uit albei se penne voortgevloei. Die outeurs se gesamentlike naskoolse opleiding strek oor meer as 30 jaar. Hulle het navorsing gedoen oor die psigologie, die fisiologie, die anatomie, die verstand en die spiritualiteit van die mens. Letterlik duisende mense het al deur hulle behandeling genesing gevind. Tog, waarsku hulle, is daar geen maklike antwoorde nie. Die menslike gemoed en emosies is 'n baie komplekse, dinamiese sisteem en in hierdie boek wou hulle die kompleksiteit in leketerme saamvat en stapsgewys riglyne vir blywende innerlike geluk verskaf.

Alreeds in die voorwoord verwoord die outeurs baie gelowiges se innerlike wroeging rakende depressie. Hulle vra byvoorbeeld vrae oor hoe dit gebeur dat daar so baie depressiewe persone onder die vurigste gelowiges gevind word; en waarom dit so dikwels gebeur dat hulle geloof, wat 'n faktor in die herstelproses moet wees, die toestand oënskynlik verder kompliseer. Gelowiges is geneig om hulself oor hulle depressie te verwyt, asof dit 'n aanduiding van ongeloof is, asook 'n onvermoë is om God te vertrou. Die gevolg hiervan is dat dit tot verdere angstigheid, onderdrukte vrese, onsekerhede en woede lei; baie dikwels word hierdie gevoelens agter 'n glimlagmasker weggesteek. Die outeurs verwys verder na die bekende probleem van fragmentasie, deurdat baie navorsers geneig is om geloof en wetenskap teenoor mekaar te stel in plaas daarvan om dit te kombineer. Dit is ten opsigte van hierdie aspek waar die outeurs suksesvol en gesagsvol geloof en wetenskap integreer om depressielyers tot genesing te begelei. Die deurlopende tema in die boek is dat elke mens so gelukkig is soos wat elkeen kies om te wees - woorde wat lank gelede deur Abraham Lincoln geuiter is.

Die teikenmark van die boek is almal wat al die een of die ander tyd in hulle lewe depressief gevoel het as gevolg van die stres en die druk van die lewe. Die boek is ook vir diegene wat al deur die storms en teleurstellings van die lewe platgeslaan is en getwyfel het of hulle ooit weer daarvan sou herstel. Die outeurs redeneer dat baie mense ongelukkig bly omdat hulle nie glo dat hulle gelukkig kan wees nie. Met die hulp van God en die mens se gesonde keuses tot geluk, kan elkeen egter innerlike vrede en blymoedigheid ervaar. Deur al die eeue het mense gevra na die essensie van geluk. Sokrates, Plato, Aleksander die Grote, Freud, Pavlov, Piaget, James en Rogers het elkeen 'n eie verduideliking en verklaring van die term geluk gehad. Die woordeboek beskryf geluk as 'n subjektiewe gevoel van welsyn. In hierdie boek beklemtoon die outeurs geluk deur dit as die proses van 'n reeks keuses te beskryf. Die keuses is die volgende:

- Wees goed vir ander mense deur altyd Christus se liefde uit te leef.

- Fokus daarop en kies gesonde gedrag wat bevorderlik vir jou eie en jou naaste se omstandighede sal wees.

- Beveg verkeerde denke met die Woord van God. Ken die Woord en memoriseer verse wat herroep kan word wanneer 'n mens dit nodig kry.

- Praat oor seerkry. 'n Seer wat toegemaak word, vorm 'n abses wat later tot groter skade kan lei.

- Sluit aan by 'n gemeente waar Christus geëer word en laat toe dat Hy en die medegelowiges jou afhanklikheidsbehoeftes vervul.

- Oorweeg mediese behandeling wanneer dit nodig blyk te wees. Oorwin die onkunde hieromtrent deur die inwin van kennis.

- Leef met jou oë gefokus op en jou hart gedraai na God toe. 
Die boek is in drie dele verdeel. In die eerste gedeelte word die vraag gevra wat depressie is. Depressie word beskryf as 'n term wat deur leke gebruik word om 'n wye spektrum neerslagtige emosies te beskryf. Depressie is ook al as die 'verkoue' van psigiese afwykings beskryf. Die outeurs beantwoord vrae soos wie depressief raak, die simptome van depressie, of selfdood sonde is en of reaktiewe smart dieselfde as depressie is.

In die tweede gedeelte word aandag aan die oorsake van depressie geskenk en die lesers word stelselmatig begelei om by die dieperliggende wortel van die probleem uit te kom. Aspekte soos genetiese faktore en die hoofoorsake vir emosionele pyn word bespreek. Stresfaktore en persoonlikheidsdinamika word ook aan die orde gestel.

In die derde afdeling word riglyne gegee hoe die mens depressie kan oorwin. In hierdie afdeling slaag die outeurs gesagvol daarin om geloof en wetenskap te integreer. Basiese riglyne vir 'n gelukkige lewe, gebaseer op Woordbeginsels, word bespreek. Riglyne word ook verskaf hoe om woede en angs te oorkom en die mites rondom die gebruik van medikasie en hospitalisering word hokgeslaan. Die laaste hoofstuk word aan die verkryging van lewenslange geluk gewy.

Die boek eindig met drie bylaes wat die klassifikasie van depressie, die verskillende soorte beskikbare medikasie en die behandeling van depressie, asook gevallestudies bespreek.

Die doel van die boek is om mense te help om ware geluk en $\sin$ in die lewe te vind te midde van die pyn en chaos wat onvermydelik deel van hierdie gevalle wêreld is. Die outeurs dien as rigtingwysers na God toe, sodat elke mens God en mekaar in liefde kan dien. 